\title{
Defining an approach for contaminated land management in the context of mine reclamation in the historic Comstock mining district, Nevada, USA
}

R. Warrender SRK Consulting (UK) Ltd, UK

A. Prestia SRK Consulting (USA) Inc., USA

R.J. Bowell SRK Consulting (UK) Ltd, UK

C. Byrns Comstock Mining Inc., USA

B. Rakvica McGinley \& Associates, USA

J. Spidell Kautz Environmental Consultants, Inc., USA

\begin{abstract}
Many abandoned mine sites are characterised by elevated concentrations of environmentally sensitive elements such as arsenic, lead and mercury that can cause contamination of surrounding soil and water resources and may have associated ecological and health impacts. Often these sites have important historic and cultural values that require access to be maintained, despite potential toxicity of the waste. Detailed site characterisation is therefore essential to ensure implementation of appropriate management measures and prevent potential impact to receptors.

This paper presents an approach to evaluating potential environmental impacts in a historically important mining district, the Comstock gold and silver mining district in Nevada, USA. For this site, geochemical soil surveys demonstrate elevated levels of arsenic, lead and mercury that are influenced by anomalous geological background concentrations connected to bedrock mineralisation, placement of mineralised waste rock and element redistribution around sites of mineral processing. The goal of the data evaluation is to develop screening levels against which geochemical data could be compared and classified for purposes of management of the materials on-site. A common approach for contaminated land is the application of normal probability plots. However, where materials have been influenced by different processes (e.g., hydrothermal mineralisation, supergene weathering, mining and processing), the inherent differences in these materials may mask or overshadow geochemical anomalies and such an approach is flawed. In order to compensate for these differences, a site-specific mineralogical and uni-variant statistical approach has been applied. This approach can be used as an initial (Tier 1) screening tool to isolate undisturbed mineralised outcrop from disturbed areas or mine waste.

Further evaluation of the geochemical data can then be undertaken as part of a Tier 2 assessment, including an assessment of contaminant bioavailability and leachability using selective extraction and physiologically based extraction tests. A Tier 3 assess would then involve the employment of geochemical predictive calculations to determine the potential of contaminants to disseminate in the environment. In this way, the areas demarked as having potential to impact the environment and interact with a receptor can be identified and appropriate management strategies implemented. This approach has the benefit of controlling costs and protecting the cultural value of historic mining areas while still allowing protection of the environment and mitigation of potential future environmental impacts.
\end{abstract}

\section{$1 \quad$ Introduction}

Legacy mine sites that are the result of abandoned operations are often characterised by elevated concentrations of environmentally sensitive elements such as arsenic, lead and mercury due to poor 
historical management of mine waste or drainage (Lottermoser, 2003; Rytuba, 2005; Frau et al., 2009; González et al., 2012; Bowell et al., 2013). This can result in contamination of surrounding soil and water resources and may have associated ecological and human health impacts. In spite of this, many historical mining sites have also become sites of economic, historic and cultural value that require access be maintained, despite potential toxicity of the mine waste. Detailed site characterisation is therefore essential to ensure appropriate management measures are implemented to prevent potential impact to receptors while being sensitive to requirements of all stakeholders and the preservation of cultural heritage. In order to distinguish between anthropogenic and natural metal enrichment within the mining area and maintain areas of economic and cultural importance, a phased and site-specific approach to determine potential impacts is advocated in this paper and is illustrated with a case study of the Comstock mining district in Nevada, USA (Figure 1).

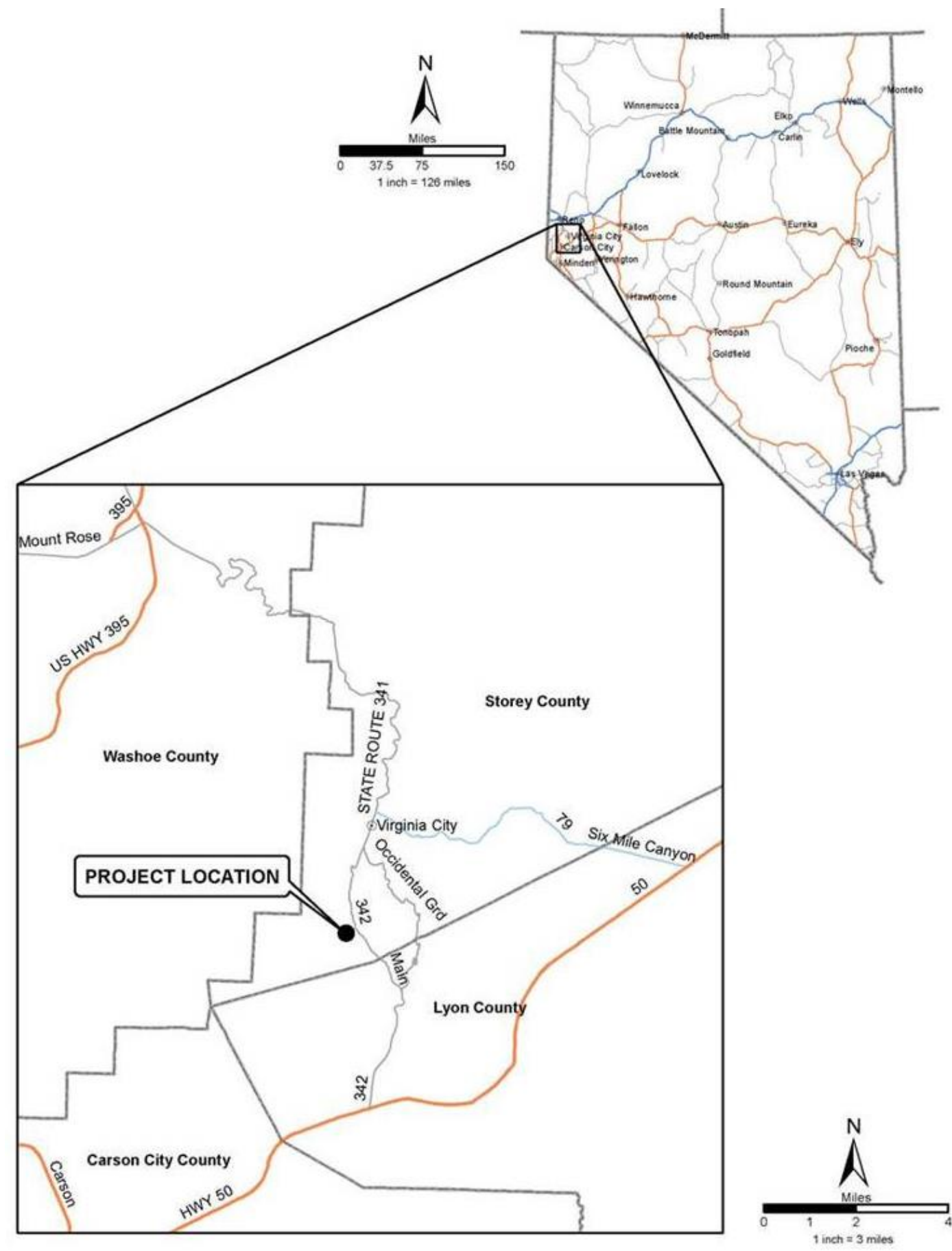

Figure 1 Location map, Comstock mining district, Nevada, USA 


\section{Background}

The mineral resources of the Comstock district represented one of the largest precious metal deposits developed in the world, with more than 11 million US short tons of ore mined, producing in excess of US\$ 396 millon in silver and gold (Bonham, 1969; Smith, 1943; Smith and Tingley, 1998). Development of the mineral resources on the Comstock resulted in the invention and implementation of new mining and milling techniques on an industrial scale. The mining industry pioneered on the Comstock served as a model that would be recreated throughout the western United States, influencing the region's development as new mineral deposits were identified.

The Comstock mineralisation is hosted in Miocene age hydrothermal systems developed within a series of Mesozoic metasedimentary and igneous rocks that are overlain by Oligocene to Miocene ash-flow tuffs (Hudson, 2003). Twelve hydrothermal alteration assemblages are recognised in the Comstock district, which are assigned to deep low sulphidation alteration or intermediate-depth high sulphidation alteration using the classification scheme of Hedenquist et al. (2000) (Hudson, 2003).

The legacy of mining in the Comstock district resulted in a total of 250 historic mill sites that are potential sources of metal (loid)s, in particular mercury, lead and arsenic. Many of these mill sites are on a national register of historic buildings and are some of the few remaining examples of nineteenth-century metallurgy in the United States. The concentrations of mercury, lead and arsenic in the historic mining district are related to ore treatment methods, which varied throughout the Comstock era from smelting through amalgamation to cyanidation. In addition, concentrations of arsenic and lead within the mill tailings and mine waste are related to the natural abundance of these constituents in the ore. Therefore, an understanding of the evolution of milling processes and the ore processing history of major mills in the area is important to understanding the geochemical dispersion of mercury, lead and arsenic across the area. Mining in the Comstock district started in 1850 and initially involved dry panning or excavation of the surface weathered ore. However, the metallurgically complex nature of the unweathered Comstock ore body (referred to as the Comstock Lode) and the presence of a silver-rich clay matrix soon required the development of alternative methods of milling and processing to extract the precious metals.

Because of the unique geologic and mineralogical conditions, Comstock miners and mining engineers developed a number of innovative technologies to maximise the efficiency and profitability of the mines. The Mexican miners introduced their method of arrastras, which involved grinding the ore followed by the addition of water, salt and copper sulphates to form a paste and then the introduction of mercury to form an amalgam. This method was known as the 'patio process'; however, at more than 2,000 $\mathrm{m}$ in elevation, with long, cold winters, not enough heat was generated to make the patio process practicable. As a result, the first stamp mills were introduced to the district in 1860.

The amalgamation process that accompanied the stamp milling proved ineffective on the silver ore sourced from the surrounding mines. In response, the Washoe Pan Process was developed, which utilised a finergrained pulp with high degrees of heat. Typically the process used 1 ton of mercury for every 10 tons of ore processed and lost virtually all of this to the environment in drainage or atmospheric discharge (Smith and Tingley, 1998; Rytuba, 2005).

With the introduction of ore processing by cyanidation to the region in the 1890 s, previously uneconomical low-grade deposits became potentially large sources of revenue. Cyanide processing had one principal advantage over pan-amalgamation: increased recovery rates. It allowed for low-grade ores and the tailings of previously treated ores to be economically processed. In 1935, 13 mills were operating on the Comstock; of these, 4 were flotation, 3 were cyanide, and 6 were older pan-amalgamation mills incorporating chemical flotation (Gardner and Carpenter, 1935). By the 1940s, many of the Comstock mills had either incorporated or were strictly cyanide mills (Stoddard and Carpenter, 1950). Production records for the region suggest that by 1952 mining on the Comstock was virtually non-existent, with only 14 tons of recorded production for the entire region (Smith and Tingley, 1998). 
As with many legacy mining areas, the lack of historical environmental management on the Comstock has led to impacts of the surrounding soil. The Carson River Mercury Site (CRMS) was designated a National Priority Listed site under the Comprehensive Environmental Response Compensation and Liability Act (the Superfund) in August 1990. Mercury has been identified as the primary contaminant of potential concern (COPC) within the CRMS as a result of the significant amounts that were introduced to the area through mineral processing (i.e., mercury amalgamation) during the late nineteenth century. Although there is a small amount of naturally occurring mercury in the Comstock ore, this source is considered minor relative to the large amount of anthropogenic mercury imported to the region during the Comstock era.

Arsenic and lead have also been identified by the U.S. Environmental Protection Agency (USEPA) as COPCS for the CRMS due to their potential to be 'concentrated' by the milling process and released to the environment. Unlike mercury, both arsenic and lead are both naturally elevated through geological processes in the Comstock ore as well as anthropogenic processes (i.e., ore beneficiation). Therefore, concentrations of lead and arsenic in the district are a combination of background levels overprinted by ore processing factors. In contrast, the majority of mercury in the area is most likely an artifact of mineral processing techniques that involved mercury amalgamation to recover gold and silver. Therefore, the focus of this study was to define 'naturally elevated background' arsenic and lead concentrations resulting from primary mineralisation within the Comstock District. To address this point, geochemical data from a range of undisturbed (i.e., in situ) and disturbed (i.e., anthropogenically influenced) materials were compared (Figure 2).

\section{Methodology}

A geochemical sampling and analysis program has been implemented to determine the source, distribution and relative concentrations of arsenic, lead and mercury in the Comstock district. The results of this will ultimately be used to inform management of material in the area.

\subsection{Mineralogy}

A mineralogical study was completed on ore and wallrock samples collected from the Billy the Kid (BTK) and Lucerne pits to understand the influence of primary mineralisation on arsenic, lead and mercury distribution. Work was completed at the School of Earth and Ocean Sciences, Cardiff University, UK and included optical microscopy, semi-quantitative scanning electron microscopy (SEM) and electron microprobe analysis.

\subsection{Soil geochemistry}

A comprehensive soil sampling and analysis program was completed to determine the spatial extent and depth of arsenic, lead and mercury within sediments and soils in the district. A total of over 2,600 samples were collected as part of this program, with samples being collected from near-surface $(<0.15 \mathrm{~m})$ to a maximum depth of $32 \mathrm{~m}$ within potential risk zones identified within the CRMS. These samples were collected in support of the Sampling and Analysis Plan for the Carson River Mercury Superfund site. Analysis of arsenic, lead and mercury was undertaken on the samples following an aqua regia digest.

\subsection{Selective extraction}

A nine-step selective extraction procedure was undertaken by ACZ laboratories, Colorado, on seven surface soil samples collected from mill sites to determine the partitioning and chemical nature of arsenic, mercury and lead within the Comstock district based on the scheme presented by Bowell et al. (2013). The method targets soluble salts and adsorbed ions in addition to amorphous and crystalline phases using the extraction steps described in Table 1. 

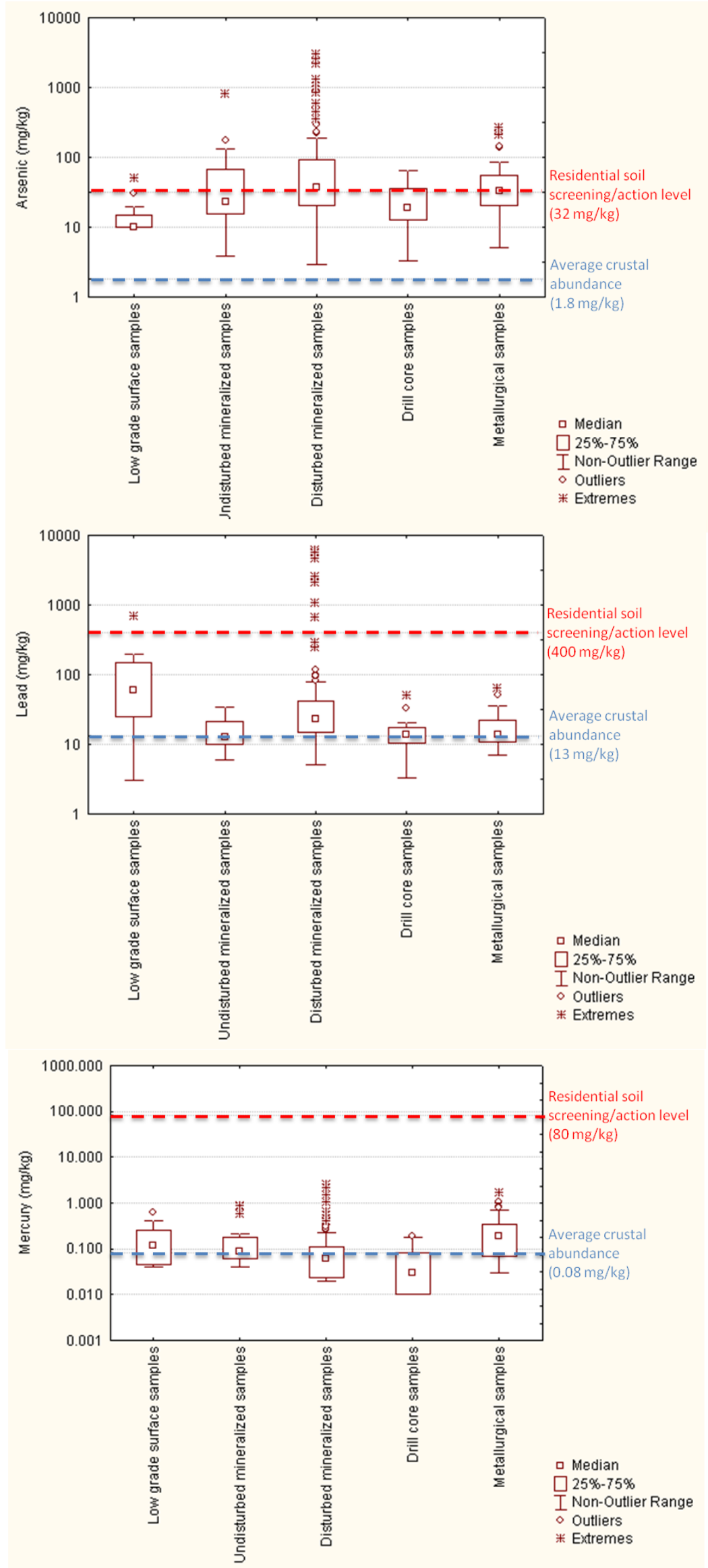

Figure 2 Box and whisker plots of arsenic, lead and mercury concentrations by source 
Table 1 Selective extraction steps (after Bowell et al., 2013)

\begin{tabular}{cc}
\hline Extractant & Fraction \\
\hline Deionised water & Water soluble fraction \\
$1 \mathrm{M}$ magnesium chloride & $\begin{array}{c}\text { lonically bound fraction } \\
\text { Strongly adsorbed fraction }\end{array}$ \\
$1 \mathrm{M}$ sodium phosphate $\left(\mathrm{NaH}_{2} \mathrm{PO}_{4}\right)$ & Carbonate fraction \\
$1 \mathrm{M}$ hydrochloric acid & Amorphous iron-aluminium oxides \\
$0.2 \mathrm{M}$ oxalic acid & Crystalline iron-aluminium oxides \\
$0.05 \mathrm{M} \mathrm{Ti}(\mathrm{III})$-citrate-EDTA-bicarbonate & Silicates and arsenic oxides \\
$10 \mathrm{M}$ hydrofluoric acid & Iron, copper and arsenic sulphides \\
$16 \mathrm{M}$ nitric acid & Zinc and other sulphides \\
\hline
\end{tabular}

\subsection{Biotoxicological tests}

To quantify bioavailability of the metals, a physiologically based extraction test (PBET) was undertaken by the Fehling Group (2012) on soil samples from several mill sites. The testing simulates the leaching of a solid matrix in the human gastrointestinal tract. This determines the bioaccessibility of a particular element (i.e., the total fraction that is available for adsorption during transit through the small intestine) (Ruby et al., 1999). From these results, site-specific risk-based soil concentrations (RBCs) were developed for arsenic and lead.

\subsection{Geochemical data review}

Several additional sources of geochemical data were reviewed to assist with evaluation of arsenic, lead and mercury distribution in the Comstock district. Geochemical data included in this review were from the following samples:

- Low-grade surface samples - 16 samples were collected from the surface in low-grade mineralised zones.

- Undisturbed mineralised samples - 20 samples were collected by Comstock Mining that are representative of mineralised material that has not been historically disturbed.

- Disturbed mineralised samples - 163 surface grab samples were collected by Comstock geologists from mineralised areas in pit walls, outcrop, talus slopes and waste rock dumps from various exploration targets throughout the district.

- Drill core samples - 31 samples were collected from drill cores for purposes of waste rock material characterisation. These samples represent undisturbed waste grade and low-grade ore material from the BTK and Lucerne deposits.

- Metallurgical samples - 61 samples from the Comstock metallurgical testing program were collected that represent undisturbed ore grade material associated with the BTK/Lucerne deposit.

The results from these samples were compiled and evaluated to define 'naturally elevated background' mercury, lead and arsenic concentrations that could be expected to occur as a result of primary mineralisation within the Comstock district. 


\section{$4 \quad$ Results}

\subsection{Geochemical and mineralogical assessment}

The mineralogical analysis demonstrates that pyrite is the most common and abundant arsenic-bearing mineral in the mineralised loads of the Comstock district and can host up to $12 \mathrm{wt} \%$ arsenic. This is followed by arsenopyrite and arsenic-bearing silver sulphosalts such as proustite $\left(\mathrm{Ag}_{3} \mathrm{AsS}_{3}\right)$ and pearceite $\left.\left(\left[\mathrm{Ag}_{8} \mathrm{CuS}_{4}\right)\right]\left[\left(\mathrm{AgCu}_{6}\right)(\mathrm{As}, \mathrm{Sb})_{2} \mathrm{~S}_{7}\right]\right)$. In addition, native arsenic, arsenolite $\left(\mathrm{As}_{2} \mathrm{O}_{3}\right)$ and scorodite $\left(\mathrm{Fe}^{3+} \mathrm{AsO}_{4} .2 \mathrm{H}_{2} \mathrm{O}\right)$ have been reported in the oxide zone of mines in the central part of the Comstock (Anthony et al., 2013). The Comstock orebody also contains lead, primarily in the form of the lead sulphide mineral galena (Cathro, 2008) and lead sulphosalts. Jarosite may also contain trace levels of lead. Mercury minerals are generally absent from the Comstock mineralisation, and mercury is only found to occur as a trace element in the zinc sulphide mineral sphalerite, with only two known mercury phases, including moschellandsbergite $\left(\mathrm{Ag}_{2} \mathrm{Hg}_{3}\right)$ and kolymite $\left(\mathrm{Cu}_{7} \mathrm{Hg}_{6}\right)$, present in trace amounts.

Multi-element data from over 2,600 samples of soil, mineralised rock and unmineralised material were analysed to determine the range of mercury, lead and arsenic concentrations in the district and the spatial distribution of contamination. Results for the undisturbed (i.e., in situ) and disturbed (i.e., anthropogenically influenced) samples were compared against average crustal concentrations (Mason, 1966) and to Nevada Division of Environmental Protection soil screening/action. The results generally show enrichment of arsenic, and to a lesser extent lead, in comparison to average crustal concentrations. The elevated arsenic concentrations can be attributed to the primary mineralisation at Comstock, where arsenopyrite and arsenic-bearing silver sulphosalts have been identified. The elevated lead concentrations are also likely related to the primary mineralisation, with galena having been identified as an abundant accessory sulphide mineral. Mercury concentrations are generally at or below average crustal abundance, particularly in the drill core samples, which are representative of in-situ, unmineralised material.

The results from surface grab samples collected from exploration targets throughout the district (i.e., disturbed mineralised rock) show that arsenic is elevated above average crustal concentrations in the surface material, with concentrations reaching a maximum of $3,000 \mathrm{mg} / \mathrm{kg}$ in the Oest area. Arsenic was also found to be elevated above the residential soil screening/action level of $32 \mathrm{mg} / \mathrm{kg}$ in $57 \%$ of the grab samples, which is attributable to the primary mineralisation, since these materials, although disturbed by anthropogenic activities, have not been processed. The elevated arsenic concentrations observed in the surface grab samples may also be partially related to the sampling method, with samples being preferentially collected from mineralised rock and waste rock dumps, where trace elements are likely to be concentrated. Lead was also found to be elevated in the majority of the surface grab samples, with concentrations exceeding 10,000 at Oest area, compared with an average crustal abundance of $13 \mathrm{mg} / \mathrm{kg}$ (Mason, 1966). Again, this is likely related to the primary mineralisation at Comstock. Nonetheless, lead concentrations in the surface grab samples were typically below the residential soil screening/action level of $400 \mathrm{mg} / \mathrm{kg}$.

Mercury concentrations for the surface grab samples collected from exploration targets were more variable between sampling areas, with samples collected from Lucerne and Hartford typically being characterised by higher mercury contents than samples collected from the Comet and Justice Pit areas. This may be related to the greater number of former mill sites identified in the Lucerne and Hartford Resource area. Although approximately $38 \%$ of samples collected contained mercury at concentrations greater than average crustal abundance $(0.08 \mathrm{mg} / \mathrm{kg})$, none of the grab samples were characterised by mercury content greater than the residential soil screening/action level of $80 \mathrm{mg} / \mathrm{kg}$.

\subsection{Assessment of metal partitioning}

The selective extraction results demonstrate that the majority of arsenic (typically $60-70 \%$ ) is associated with sulphide minerals, particularly iron sulphides (e.g., pyrite - $\mathrm{FeS}_{2}$ ). This is consistent with the mineralogical work, which identified pyrite and arsenopyrite as the main arsenic-bearing mineral phases in 
the Comstock mineralisation. In contrast, samples with higher total arsenic concentrations (e.g., PA8-0-6" and NY7-0-6") show a greater proportion of arsenic associated with carbonate phases and adsorbed onto amorphous iron oxides (Figure 3). Arsenic has a strong affinity for iron oxides (Bowell, 1994), which are likely to be ubiquitous in the oxidised surface soils in the vicinity of the mill sites. The results of the selective extraction are consistent with this observation and indicate that typically $10-20 \%$ of arsenic is associated with (i.e., adsorbed onto) amorphous iron oxides. Any arsenic associated with carbonate phases is likely to be in the form of arsenate minerals (e.g., pharmacosiderite $\left[\mathrm{KFe}_{4}{ }^{3+}\left(\mathrm{AsO}_{4}\right)_{3}(\mathrm{OH})_{4} .7 \mathrm{H}_{2} \mathrm{O}\right]$ ) and low solubility copper-zinc arsenates. Generally a very low proportion $(<0.5 \%)$ of arsenic was found to be water-soluble or ionically bound, indicating the majority of arsenic in the vicinity of the mill sites is not labile.

Lead was typically found to be associated with carbonate or sulphide phases. Generally $30 \%$ was associated with carbonates, approximately $20-30 \%$ with iron sulphides and a further $10-20 \%$ with other sulphide phases. The mineralogical work indicates that lead is primarily present in the form of the sulphide mineral galena $(\mathrm{PbS})$, with minor lead also occurring as lead sulphosalts and as a trace element in jarosite $\left(\mathrm{KFe}_{3}\left(\mathrm{SO}_{4}\right)_{2}(\mathrm{OH})_{6}\right)(\mathrm{SRK}, 2012)$. This observation is generally consistent with the selective extraction results, which showed typically between $40 \%$ and $70 \%$ of lead associated with sulphide phases. Samples with higher total lead concentrations (e.g., PA5-0-6", NY-15-0-6" and DM7B-0-6") generally showed a greater proportion ( $\sim 50 \%$ ) of lead associated with carbonate mineral phases (Figure 3 ). This is likely to be in the form of the lead carbonate mineral cerussite $\left(\mathrm{PbCO}_{3}\right)$. The low proportion of lead in the mobile fractions (i.e., water soluble or ionically bound phases) (typically $<0.5 \%$ ), indicates the majority of lead is not labile.

The selective extraction data indicate that typically $70 \%$ of mercury is associated with iron sulphide phases and the remaining $30 \%$ is associated with zinc and other sulphides. There is typically a very low proportion of mercury in the mobile fractions (i.e., in the early extraction steps). This low percentage of leachable mercury in the samples indicates that highly soluble or exchangeable mercury species are not the dominant phases in the mill tailings and that the mercury is strongly bound to mineral phases (i.e., it is not bioavailable). Furthermore, the association of mercury with sulphide phases indicates that it is chemically stable and is likely to remain in the soil. This perhaps reflects the fact that any labile mercury present would be highly mobile and has been lost, and the residual portion of mercury present has been stable since the end of the nineteenth century and is likely to continue to be stable on a geological time scale.

A study by Kim et al. (2004) investigated mercury speciation in samples from gold mining regions where elemental mercury was introduced to aid in the gold recovery process. This study identified the presence of mercury sulphides and schuetteite $\left(\mathrm{Hg}_{3}\left(\mathrm{SO}_{4}\right) \mathrm{O}_{2}\right)$ in the mill tailings, which may have formed as a result of long-term burial of elemental mercury in reducing high-sulphide sediment. It is therefore likely that much of the elemental mercury in the vicinity of the Comstock mill sites has been converted to a more stable form. This transformation of elemental mercury $\left(\mathrm{Hg}^{0}\right)$ to less mobile and toxic forms over time will ultimately reduce the environmental impact of elemental mercury contamination.

Most of the material used in this study has been exposed to weathering for as much as 150 years, and the samples were collected from the surface. Therefore, most of the highly volatile and soluble mercury species are likely to have been removed (Sladek and Gustin, 2003). In addition, $\mathrm{Hg}^{0}$ remaining at the surface from mineral processing is likely to have been oxidised to $\mathrm{Hg}^{2+}$, therefore explaining the low proportion of mobile mercury in the surface samples at the mill sites. 

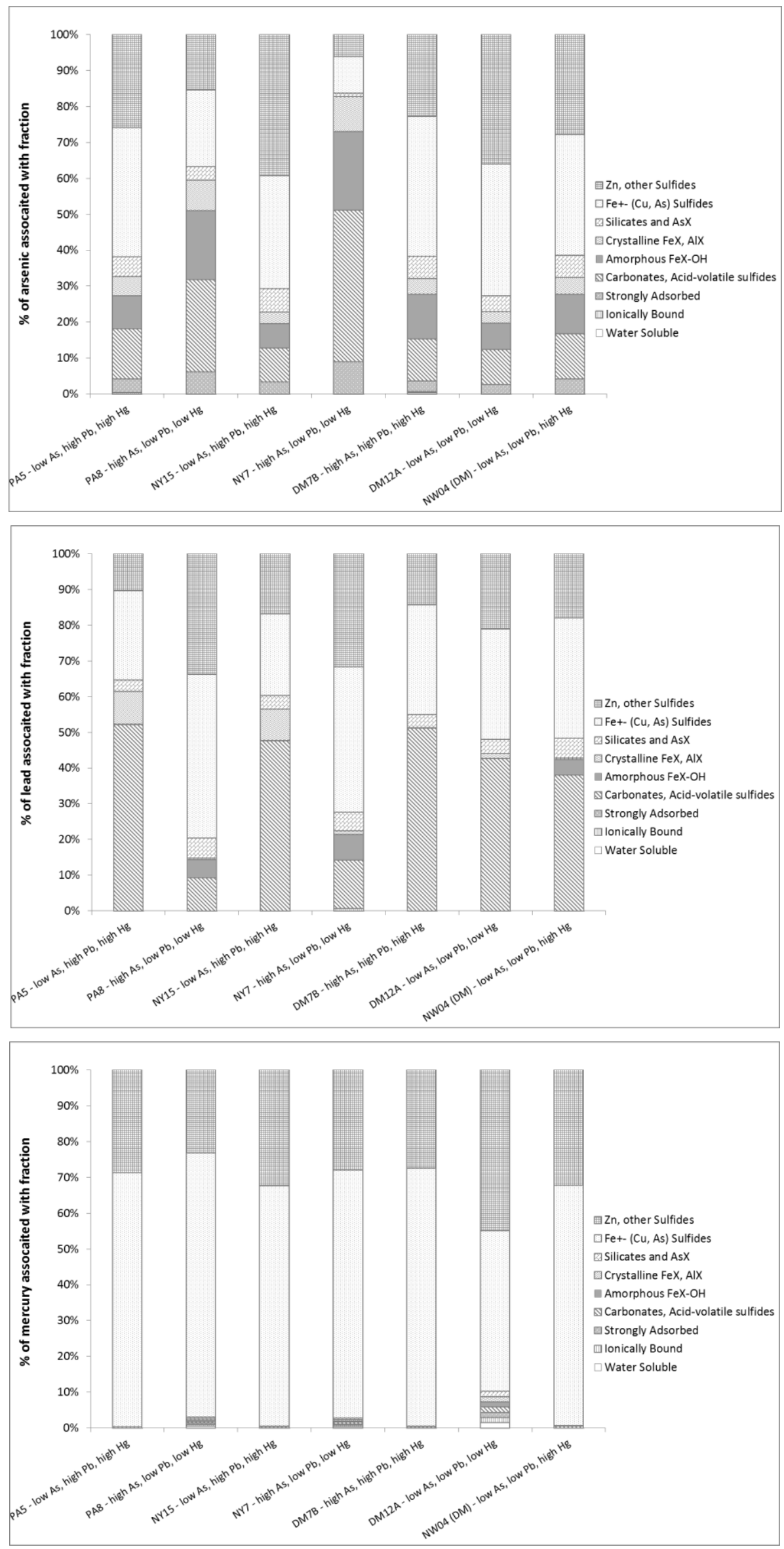


\section{Figure 3 Selective extraction results for arsenic (top), lead (middle) and mercury (bottom)}

\subsection{Bioaccessibility evaluation}

A risk assessment has been completed to determine site-specific risk-based soil concentrations for arsenic and lead. This risk assessment was based on results from the PBET for several samples collected from mill sites within the Comstock (Fehling Group, 2012) (c.f. Ruby et al., 1999).

A deterministic (e.g., point estimate) analysis was used to calculate the site-specific RBC for arsenic, based on both the cancer and non-cancer toxicological endpoints. For the cancer endpoint, a theoretical target risk level of $1 \times 10^{-4}$ ( 1 in 10,000) and the USEPA's oral slope factor for arsenic (USEPA, 2012) were used. The USEPA target risk range of $1 \times 10^{-6}(1$ in $1,000,000)$ to $1 \times 10^{-4}(1$ in 10,000$)$ (USEPA, 1990) was considered, but the population of interest (mine workers) is much less than 1,000,000 (at less than 150), so the higher end of USEPA's target risk range was selected for the cancer endpoint and is consistent with USEPA policy (1990). For the non-cancer endpoint, a target hazard index of 1.0 and the USEPA reference concentration and reference dose were used.

The target risk level and target hazard index are consistent with USEPA guidance and, specifically, the Record of Decision for the CRMS in which portions of the Comstock site are included (USEPA, 1995). The lower of the two arsenic soil RBCs (non-cancer endpoint and cancer endpoint) was selected as the final soil criterion. The results of this analysis indicate that the arsenic site-specific RBC for soil is $384 \mathrm{mg} / \mathrm{kg}$, which is based on the non-cancer endpoint. The associated cancer risk for this soil concentration is $3 \times 10^{-5}$ ( 3 in 100,000).

For lead, the USEPA Adult Lead Model (ALM) (USEPA, 2003) was used to derive a soil criterion. For lead, the site-specific soil RBC is $1,013 \mathrm{mg} / \mathrm{kg}$ and, based on the USEPA model used, is protective of a pregnant worker's fetus at $10 \mu \mathrm{g} / \mathrm{dL}$ of lead in blood (USEPA, 2003).

\subsection{Mill area evaluation}

Soil geochemistry data have been reviewed in the context of the mining/milling history, mineralisation and geochemistry of the Comstock district for each of the mill areas identified with the CRMS. Suitable criteria were identified for mercury, lead and arsenic and applied to determine where mitigation and/or cleanup was required or to identify which mill areas within the CRMS could be removed from further evaluation. A flow chart was developed that illustrates the decision process utilised during the data review and evaluation (Figure 4). Based on this approach, management recommendations were developed for each of the mill areas identified with the CRMS. A few of the mills areas that were included in this evaluation are summarised in Table 2, along with the resulting management recommendations, as an example. 


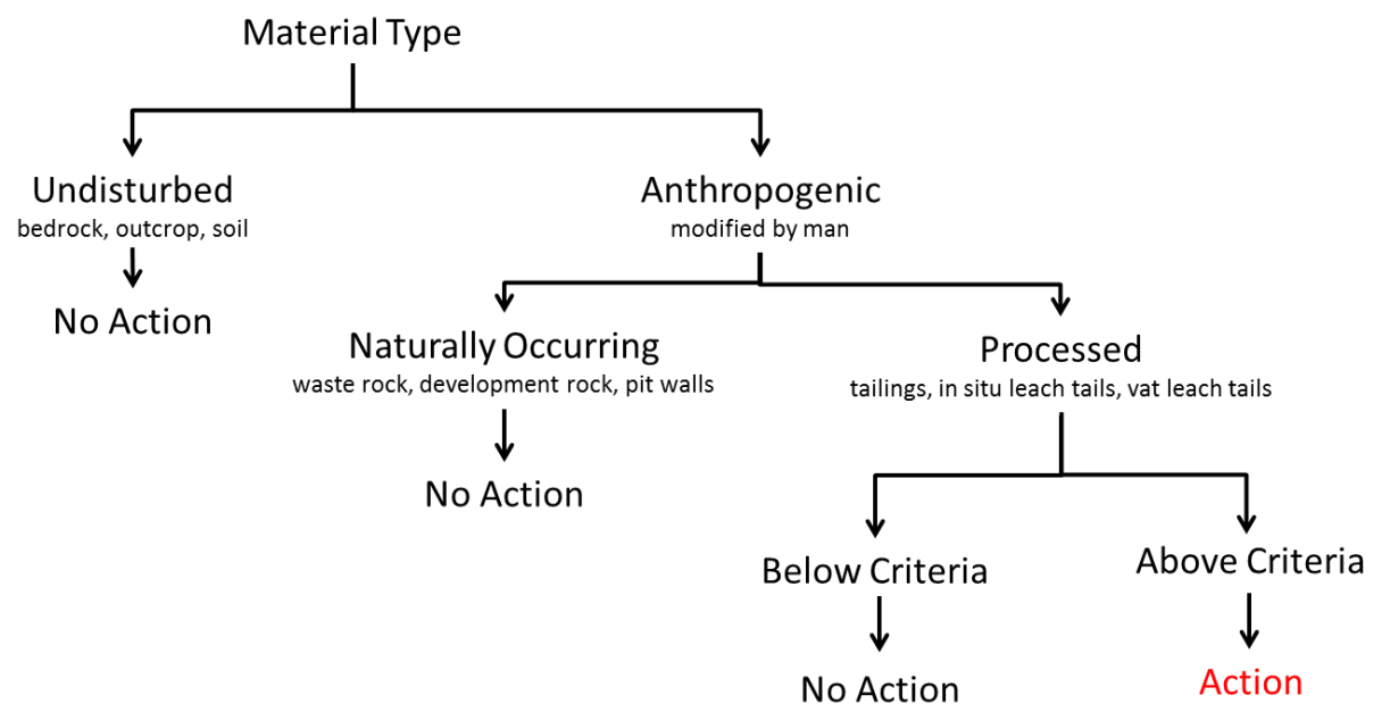

Figure 4 Decision tree approach to mill area evaluation

Table 2 Example of mill areas included in the data evaluation

\begin{tabular}{|c|c|c|c|}
\hline Mill & Process & Year(s) & Recommendation \\
\hline Bowers Mill & Mercury amalgamation & $1860 s-1869$ & $\begin{array}{l}\text { Monitoring required, } \\
\text { no further action }\end{array}$ \\
\hline Yellow Jacket Mill & Cyanide Mill & 1908 & $\begin{array}{l}\text { Monitoring required, } \\
\text { no further action }\end{array}$ \\
\hline Sapphire Mill & Mercury amalgamation & $1860 s-1880$ & Remediation required \\
\hline Imperial Mill & Mercury amalgamation & 1862-1880s & Remediation required \\
\hline Empire Mill & Washoe pan & 1861 & No further action \\
\hline Con Chollar Mill & Flotation and cyanide & 1933-1950s & No further action \\
\hline Globe \& Lindsay Mill & Mercury amalgamation & $1860 \mathrm{~s}$ & Remediation required \\
\hline Boston Mill & Mercury amalgamation & $1870 \mathrm{~s}$ & Remediation required \\
\hline Hartford Mill & Cyanide & 1935-1940 & No further action \\
\hline $\begin{array}{l}\text { Dayton Mine and the } \\
\text { Dayton Consolidated Mill }\end{array}$ & Cyanide & 1934-1948 & No further action \\
\hline
\end{tabular}

\section{$5 \quad$ Discussion of findings}

The results of the mineralogical, geochemical and bioaccessibility evaluation have been coupled with information relating to the milling history of the Comstock to better understand contaminant distribution/availability and to develop appropriate management plans. This allows effective conservation of important historic and cultural aspects of the site, while preventing potential impacts to receptors.

It is known that the general milling process employed on the Comstock before 1900 involved pulverising ore with stamp mills, creating a slurry and adding mercury to the mixture. This process created a mercury amalgam that was separated from the slurry and retorted to remove the mercury from the gold and silver. The products of this were mercury-amalgamated salts in addition to low solubility oxidised arsenic and lead minerals. After 1900, cyanide leaching and flotation processes gradually replaced amalgamation, and mining operations moved to mining lower-grade material and reworking former ore dumps and tailings 
piles. The cyanide process removes not only gold and silver but also mercury from the waste stream. Therefore, the resulting tailings would not be expected to contain mercury. As a result, the majority of the mercury released to the environment is associated with tailings generated prior to 1900 that were separated from the amalgam slurry and discharged into drainages or tailings impoundments. Other possible release mechanisms would have included air emissions from the retort, fugitive air emissions throughout the process, and spilling throughout the process where mercury was handled. It is estimated that the loss of mercury exceeded $0.5 \mathrm{~kg}$ for each ton of ore milled, for a total estimate of over 6,350 tons of mercury discharged to the environment.

Although arsenic concentrations in the Comstock district generally reflect natural geochemical anomalies related to gold and silver mineralisation in the bedrock, arsenic can also be elevated in the tailings material due to the extraction processes. However, there is no net addition of arsenic to the system during processing but rather concentration through loss of the lighter fraction. Amalgamation and gravity separation methods separate most sulphdes from the gangue minerals. Consequently, arsenic in the mill tailings produced by these methods is typically higher in comparison to arsenic concentrations in tailings produced by direct cyanidation without any pre-concentration. The occurrence of lead can also be related to primary mineralisation but is also shown to be related to concentration by extraction and processing techniques. However, the total mass of arsenic and lead in milled tailings is generally insignificant compared with the arsenic and lead related to in-situ mineralisation as a total mass.

Mills in the Comstock era commonly operated as toll mills and would process ore from various locations throughout the district as well as other nearby districts (such as the Old Soldier, Crested Pine, Walker Lake and even from the Tonopah Districts). Therefore, the actual source of ore processed in the mills cannot be tied to a single location. This fact alone limits application of uni-variant statistics in the assessment of the data in demonstrating a single source for the observed geochemistry. This is because more than one factor or variable appears to influence soil geochemistry, and this would include 'exotic' controls such as toll processing of geochemically different and distinct ores from other mining districts. Even multi-variant statistics would be limited where the assumption is that all of the material has a common control, such as similar geology, or that all contamination derives from the same type of mineralised material; thus it would not necessarily be possible to clearly delineate controlling trends in the data.

Based on a geological understanding of the deposit, it is known that both lead and arsenic are present in anomalous concentrations associated with bedrock mineralisation (Hudson, 2003). In addition, it has been shown that these elements occur in the mine waste materials along with anomalous mercury (Tidball et al., 1991). Where anomalous levels of lead and arsenic occur in the absence of mercury, then these are representative of naturally elevated background conditions. Although there is a small amount of naturally occurring mercury in the Comstock ore, this source is considered minor relative to the large amount of anthropogenic mercury imported to the region during the Comstock era. Therefore, mercury within the area can be solely attributed to an anthropogenic source. Conversely, the primary control on arsenic and lead concentration throughout the district is primary mineralisation, which can be overprinted by anthropogenic processes. The effects of separation and isolation of arsenic and lead as a result of milling are likely to be insignificant in comparison with the mass of these elements that can be attributed to primary mineralisation.

\section{Conclusions}

This paper presents a case study of a legacy mining district with important historic and cultural values where surface materials have been impacted by anthropogenic activities. The Comstock mining district contains areas of surface sediment and soil that contain elevated and bioavailable metal(loids)s. The focus of this study was to identify areas of potential contamination that require management based on sitespecific criteria developed for constituents of concern, including mercury, lead and arsenic.

This study required a multi-disciplinary approach in order to identify the main controls on the dispersion of mercury, lead and arsenic in the Comstock district and determine at what levels these constituents present 
a risk to the environment and human health. As part of this study, a geochemical and mineralogical evaluation of surficial materials was completed to determine the most applicable indicators of contamination as opposed to background geochemical anomalies relating to the primary mineralisation. A historical overview of the area was also developed that provides an in-depth discussion of anthropogenic impacts associated with historic mining and mineral processing and the cultural context of material located at each of the mill sites within the Comstock district. In order to address the human health risk of CRMSimpacted materials, a risk assessment was completed to determine site-specific risk-based soil concentrations for arsenic and lead. The results of these various assessments allowed for educated decisions to be made with regard to the need for mitigation of the mill sites within the CRMS.

This study has demonstrated that the geochemical controls on the occurrence of arsenic and lead in the Comstock district are different to the controls on mercury dispersion. From this study, it can be asserted that arsenic and lead concentrations in the area are mainly a reflection of natural geochemical anomalies related to gold and silver mineralisation in the bedrock. By contrast, mercury geochemistry reflects an anthropogenic source with negligible mercury associated with bedrock mineralisation. Furthermore, mills in the Comstock era commonly operated as toll mills and would process ore from various locations throughout the district as well as other nearby mining districts. Therefore, the actual source of ore processed in the mills cannot be tied to a single location. Consequently, the typical statistical approach to defining background concentrations for contaminated land is not suitable with such heterogeneous materials (Singh et al., 1997).

Qualitative assessment of the selective extraction data indicates that bioavailable or labile metal content for arsenic, lead and mercury is very low in the samples analysed (typically less than $1 \%$ of total metal for arsenic and lead and less than $5 \%$ for mercury). Consequently, biological metal uptake is not considered a risk issue for the mill sites included in the evaluation. From the PBET, site-specific criteria were developed for arsenic and lead and applied to geochemical results for soil samples collected from mill areas within the CRMS.

This study demonstrates that a site-specific approach is required to determine anthropogenic impacts and cleanup criteria for legacy mine sites. Site-specific mineralogical and geochemical characterisation is essential in the understanding of element distribution, release and bioavailability. The cultural context of legacy mine sites is also critical, and an understanding of the history of mining and mineral processing is fundamental in defining the type and extent of anthropogenic impacts. Furthermore, development of sitespecific criteria on a parameter-by-parameter basis allows appropriate management decisions to be made. Results of these assessments will allow for site boundary definition and for educated decisions to be made with regard to the need for mitigation and/or cleanup of the mill site areas.

\section{Acknowledgements}

The authors would like to acknowledge permission for this study to be published from Comstock Mining Inc.

\section{References}

Anthony, J.W., Bideaux, R.A., Bladh, K.W. and Nichols, M.C. (2013) Handbook of Mineralogy, Mineralogical Society of America, Chantilly, Va.

Bonham, H.F. (1969) Geology and Mineral Deposits of Washoe and Storey Counties, Nevada, Nevada Bureau of Mines and Geology, Bulletin, $70 \mathrm{p}$.

Bowell, R.J. (1994) Sorption of arsenic by iron oxides and oxyhydroxides in soil, Applied Geochemistry, Vol. 9, pp. $279-286$.

Bowell, R.J., Rees, S.B., Barnes, A., Prestia, A., Warrender, R. and Dey, B.M. (2013) Geochemical assessment of arsenic toxicity in mine site along the proposed Mineral Tramway Project, Camborne, Cornwall, Geochemistry, Exploration, Environment and Analysis, Vol. 13(2), in press.

Cathro, R.J. (2008) The Comstock Lode, Nevada, CIM Magazine, Vol. 3(4), pp. 61-76.

Fehling Group (2012) In Vitro Bioaccessibility Study for Arsenic and Lead, Reno, Nevada.

Frau, F., Ardau, C. and Fanfani, L. (2009) Environmental geochemistry and mineralogy of lead at the old mine area of Baccu Locci (south-east Sardinia, Italy), Journal of Geochemical Exploration, Vol. 100, pp. 105-115. 
Gardner, P.S. and Carpenter, J.A. (1935) Present Day Milling Plants on the Comstock Lode, viewed 26 July 2012, $\mathrm{ftp}: / /$ nas.library.unr.edu/keck/mining/SCANS/1200/12000006.pdf.

González, J.C.A., Cala Rivero, V. and Iribarren Campaña, I. (2012) Geochemistry and mineralogy of surface pyritic tailings impoundments at two mining sites of the Iberian Pyrite Belt (SW Spain), Environmental Earth Sciences, Vol. 65, pp. 669680.

Hedenquist, J.W., Aribas, A.R. and Golzalez-Urien, E. (2000) Exploration for epithermal gold deposits, Reviews in Economic Geology, Vol. 13, pp. 245-277.

Hudson, D.M. (2003) Epithermal alteration and mineralisation in the Comstock District, Nevada, Economic Geology, Vol. 98, pp. 367-385.

Kim, C.S., Rytuba, J.J. and Brown, Jr., G.E. (2004) Geological and anthropogenic factors influencing mercury speciation in mine wastes: an EXAFS spectroscopy study, Applied Geochemistry, Vol. 19, pp. 379-393.

Lottermoser, B. (2003) Mine Waste: Characterisation, Treatment, and Environmental Impacts, Springer, 277 p.

Mason, B. (1966) Principles of Geochemistry, 3rd edition, John Wiley, New York, 220 p.

Ruby, M.V., Schoof, R., Brattin, W., Goldade, M., Post, G., Harnois, M., Mosby, D.E., Casteel, S.W., Berti, W., Carpenter, M., Edwards, D., Cragin, D. and Chappell, W. (1999) Advances in evaluating the oral bioavailability of inorganics in soil for use in human health risk assessment, Environmental Science and Technology, Vol. 33, pp. 3,697-3,705.

Rytuba, J. (2005) Geologic and mining sources of mercury to the environment, in Mercury: Sources, Measurements, Cycles and Effects, M.B. Parsons and J.B. Percival (eds), MAC Short Course, Vol. 34, pp. 21-42.

Singh, A.K., Singh, A. and Engelhardt, M. (1997) The Lognormal Distribution in Environmental Applications. U.S. Environmental Protection Agency, Office of Research and Development.

Sladek, C. and Gustin, M.S. (2003) Evaluation of sequential and selective extraction methods for determination of mercury speciation and mobility in mine waste, Applied Geochemistry, Vol. 18, pp. 567-576.

Smith, G.H. (1943) The History of the Comstock Lode 1850-1920, Nevada Bureau of Mines Bulletin 37, 305 p.

Smith, G.H. and Tingley, J.V. (1998) The History of the Comstock Lode 1850-1997, 328 p.

SRK (2012) Relationship of Mercury, Lead and Arsenic in the South Comstock Mineral District, prepared for Comstock Mining Inc.

Stoddard, C., and Carpenter, J.A. (1950) Mineral Resources of Storey and Lyon Counties, Nevada, Geology and Mining Series No. 49, Nevada Bureau of Mines and Geology and University of Nevada Press, Reno and Las Vegas.

Tidball, R.R., Briggs, P.H., Stewart, K.C., Vaughn, R.B. and Welsch, E.P. (1991) Analytical data for soil and well core samples from the Carson River Basin, Lyon and Churchill Counties, Nevada, U.S. Geological Survey, $47 \mathrm{p}$.

USEPA (United States Environmental Protection Agency) (1990) Reducing Risk: Setting Priorities and Strategies for Environmental Protection, Science Advisory Board.

USEPA (United States Environmental Protection Agency) (1995) Record of Decision, Carson River Mercury Site, Operable Unit 1L Surface Soil.

USEPA (United States Environmental Protection Agency) (2003) Recommendations of the Technical Review Workgroup for Lead for an Approach to Assessing Risks Associated with Adult Exposures to Lead in Soil, Final (December 1996).

USEPA (United States Environmental Protection Agency) (2012) Integrated Risk Information System, http://www.epa.gov/IRIS. 